\title{
Biolistic transformation of Saccharomyces cerevisiae with $\beta$-glucosidase gene from Cellulomonas biazotea
}

\author{
S. Parvez ${ }^{*}$ Z. Mukhtar, F. Rashid, M.I. Rajoka \\ National Institute for Biotechnology \& Genetic Engineering, P.O. Box 577, Jhang Road, Faisalabad, Pakistan.
}

Accepted 27 October 2003

\begin{abstract}
A $\beta$-glucosidase genomic DNA from Cellulomonas biazotea NIAB 442 was isolated and coated onto tungsten microprojectiles for direct transformation of the gene into Saccharomyces cerevisiae. Transformation of $\beta$ glucosidase into $S$. cerevisae conferred the ability to hydrolyse esculin and cellobiose, indicating that the gene is expressed in the bombarded yeast.
\end{abstract}

Key words: Biolistic transformation, $\beta$-glucosidase, Cellulomonas biazotea, Saccharomyces cerevisiae.

\section{INTRODUCTION}

Enzymatic conversion of cellulose to metabolizable sugars is an important step in terms of their further conversion to other useful products including ethanol production. The microbial conversion of lignocellulosic biomass into useful products is a complex process and involves synergistic action of three enzymes of the cellulase complex namely endoglucanase (EC 3.2.1.4), exo-cellobiohydrolase (EC 3.2.1.91) and $\beta$-glucosidase (EC. 3.2.1.21) (Marsden and Gray, 1986).

Cellulase genes from a wide variety of micro-organisms have been isolated (Knowles et al., 1987; Gilkes et al., 1991; Penttila et al., 1989). Structural genes of different cellulases from Cellulomonas spp. have been cloned in Escherichia coli and Saccharomyces cerevisiae (Whittle et

\footnotetext{
${ }^{\star}$ Corresponding author. E-mail: sparvez@nibge.org.
}

al., 1982; Nakamura et al., 1986; Curry et al., 1988; Rajoka et al., 1992). But in this study, we report the direct transformation of chromosomal DNA encoding $\beta$-glucosidase genes from Cellulomonas biazotea into $\mathrm{cir}^{\circ}$ strain of $S$. cerevisiae; the biolistic transformant secreted gene product very efficiently in-vivo and in-vitro. This work complements the reports of Armaleo et al. (1990).

The metal microprojectiles coated with nucleic acids can be shot into yeast cells with consequent expression of the introduced genes (Klein et al., 1987). This biolistic transformation methodology was developed specifically to deliver nucleic acids through the wall of intact plant cells insitu (Sanford et al., 1987). Introduction of foreign genes to several mono and dicot plants species have been demonstrated (McCabe et al., 1988; Klein et al., 1988a,b; Finer and McMullen, 1990; Weeks et al., 1993; Chen et al., 1998; Rasco-Guant et al., 1999; Jordan, 2000; Dai et al., 2001). When the present study was initiated, the basic 
informations about the successful transformation of nucleic acids into $S$. cerevisiae and other fungi via particle bombardment were available by Armaleo et al. (1990) with the definition of physical, cellular and genetic aspects of the process. Using the well studied $S$. cerevisiae as a model system, Botstein and Fink (1988) demonstrated that the biolistic introduction of DNA into cells can lead to stably inherited modifications of the nuclear genome. The successful transformations of DNA into yeast, was also the basis for transformation of yeast mitochondria (Johnston et al., 1988; Armaleo et al., 1990). However, the direct transformation of cellulase genes into yeast cells is not available in the literature. Here we report for the first time, the introduction of $\beta$-glucosidase genes into $S$. cerevisiae.

\section{MATERIALS AND METHODS}

\section{Strains}

Cellulomonas biazotea (NIAB 442) was isolated from a bagasse heap (Rajoka and Malik, 1986). Cir $^{\circ}$ strain of S. cerevisiae, FAS-21 was a gift from International Center for Genetic Engineering and Biotechnology (ICGEB), Italy.

\section{Culture Media}

C. biazotea was grown in Dubos salts minimal medium consisting $1 \mathrm{~g}$ $\mathrm{NaNO}_{3}, 0.5 \mathrm{~g} \mathrm{KCl}, 1 \mathrm{~g} \mathrm{~K}_{2} \mathrm{HPO}_{4}, 0.5 \mathrm{~g} \mathrm{MgSO}_{4}, 0.1 \mathrm{~g} \mathrm{FeSO}_{4}$ per litre of water at $\mathrm{pH}$ 7.3.

\section{Isolation of DNA}

C. biazotea cultures $(100 \mathrm{ml})$ were grown for 20 hours and harvested by centrifugation. Chromosomal DNA was extracted from the cell pellet using cetyltrimethylammonium bromide $(C T A B)$ method of Ausubel et al. (1990). The chromosomal DNA was partially digested with Sacl.

\section{Preparation of cells for bombardment}

Biolistic PDS-1000/He, particle delivery system, Bio-Rad Laboratories, USA was used in this study. Typically, stationary phase yeast cells (36$72 \mathrm{~h}$ culture) were spread at $10^{8}$ cells/plate onto selective agar media containing either $1 \mathrm{M}$ sorbitol or $0.75 \mathrm{M}$ sorbitol and $0.75 \mathrm{M}$ mannitol. Yeast cells suspended in liquid, a stationary phase culture was spun down and resuspended in its own spent medium at $4 \times 10^{9} \mathrm{cells} / \mathrm{ml}$. One volume of this suspension was thoroughly mixed with 3 volumes of regeneration medium ( $1 \mathrm{M}$ sorbitol, $1 \mathrm{M}$ mannitol, $9 \mathrm{mg} / \mathrm{ml}$ yeast nitrogen base without amino acids, $2.67 \%$ glucose (w/v), $2.67 \%$ YEP broth ( $\mathrm{v} / \mathrm{v}), 1.33 \mathrm{mg} / \mathrm{ml}$ gelatin) and kept at room temperature for at least $15 \mathrm{~min}$ and upto $1 \mathrm{~h}$ before bombardment. Following this, $10^{8}$ cells $(100 \mu \mathrm{l})$ were spread within a one inch-diameter in a circle around the center of a plastic dish. Tunsten particles $(0.55-0.65 \mu \mathrm{m}$ in size) were sterilized and coated with the DNA following the manufacturer's instructions. Bombardment was done at a helium pressure of $900 \mathrm{Psi}$, bombardment distance ca. $9 \mathrm{~cm}$ and vacuum was kept at 25 inches of $\mathrm{Hg}$.

The transformants were selected on Dubos-esculin-Deoxy-Dglucose-ferric ammomim citrate agar medium. The positive clones converted esculin to esculitin which reacted, in turn, with ferric ions to form blackening zone. The diameter of zone of blackening (in $\mathrm{mm}$ ) was taken as measure of $\beta$-glucosidase secretion and compared for in vivo production of $\beta$-glucosidase. As soon as the plate is removed from the bombardment chamber, $1 \mathrm{ml}$ of diluted regeneration medium $(1: 1$; water: medium) was evenly distributed onto the bombarded area to prevent drying. Plates were incubated at $30^{\circ} \mathrm{C}$. The cell suspension was then scraped and spread onto selective plates (Armaleo et al., 1990). Transformed colonies became visible after 2 days.

\section{Preparation of Enzyme Extracts}

Bombarded yeast strains were grown at $30^{\circ} \mathrm{C}$ with Del Rosario's medium having $0.4 \%$ yeast extract supplemented with $1.0 \%$ cellobiose as a carbon source (Del Rosario et al., 1979). The yeast cultures were grown to late logarithmic phase using $1 \%(\mathrm{v} / \mathrm{v})$ inoculum from overnight cultures grown in the above media. Extracts were harvested by centrifuging cells in $5 \mathrm{mM}$ acetate buffer after sonicating on ice for two 3 min bursts. Cell debris was removed by centrifugation for $5 \mathrm{~min}$ at $10,000 \mathrm{rpm}$ in a Beckman microfuge-11 (Beckman, USA) and the supernatant was preserved for enzyme assay.

\section{Enzyme assays}

In vivo secretion of $\beta$-glucosidase was performed by pouring $10 \mu \mathrm{l}$ cells of equal OD on the surface of esculin-ferric ammonium citrate medium. The enzyme activity was determined by zone of blackening measured in $\mathrm{mm}$.

In vitro assays on extracellular and intracellular were performed towards p-nitrophenyl-ß-D-galactopyranoside (PNPG) or cellobiose after Nakamura and Kitamura (1982) and Rajoka and Malik (1986). Enzyme activity was expressed as units $/ \mathrm{ml} \mathrm{h}$.

\section{RESULTS AND DISCUSSION}

Yeast strains have been previously transformed with cellulase genes of $C$. biazotea for alcohol production from the cellulosic substrates. These strains transformed by biolistic particles between 0.55 and $0.65 \mu \mathrm{m}$ have just the right kinetic energy to penetrate but not to disrupt a yeast cell (Armaleo et al., 1990). Isolates were found that yielded transformation frequencies of $10^{-5}$ and $10^{-4}$. Biolistic transformation efficiencies have also been measured in $S$. pombe and the filamentous ascomycete, Neurospora crassa (Aremaleo et al., 1990). In both cases they have observed transformation efficiencies in the range of $10^{-6}$ and $10^{-7}$.

A total of 400 bombarded yeast cells were obtained, and five of these (PFR1 to PFR5) show $\beta$-glucosidase activity. The bombarded yeast strains exhibit comparable $\beta$-glucosidase activities with the donor, $C$. biazotea (Table 1). The efficiency of substrate utilization was also studied, PFR5 yeast was more efficient for the utilization of substrate (Figure 1). Results of in-vitro screening after production of enzyme in $1.0 \%$ cellobiose are shown in Figure 2. Maximum enzyme activity produced by the best bombarded yeast cells was $3.51 \mathrm{U} / \mathrm{ml} \mathrm{h}$ after $40 \mathrm{~h}$.

Structural genes of $\beta$-glucosidase from $C$. uda have been cloned into E. coli (Nakamura et al., 1986). These authors reported that the cloned genes expressed very well in the host and produced significant amount of the enzyme. We observed that $\beta$-glucosidase was secreted in the bombarded yeast cells and the level of enzyme activities was similar to 
Table 1. Production of ß-glucosidase by bombarded yeast transformants harboring restricted genomic DNA of $C$. biazotea in plate tests.

\begin{tabular}{|l|c|}
\hline Yeast Bombarded & $\begin{array}{c}\text { B-glucosidase activity } \\
\text { (diameter of zone of } \\
\text { blackening, mm) }\end{array}$ \\
\hline Control yeast & 0 \\
Donor (C. biazotea) & 31 \\
PFR1 & 30 \\
PFR2 & 20 \\
PFR3 & 29 \\
PFR4 & 31 \\
PFR5 & 34 \\
\hline
\end{tabular}

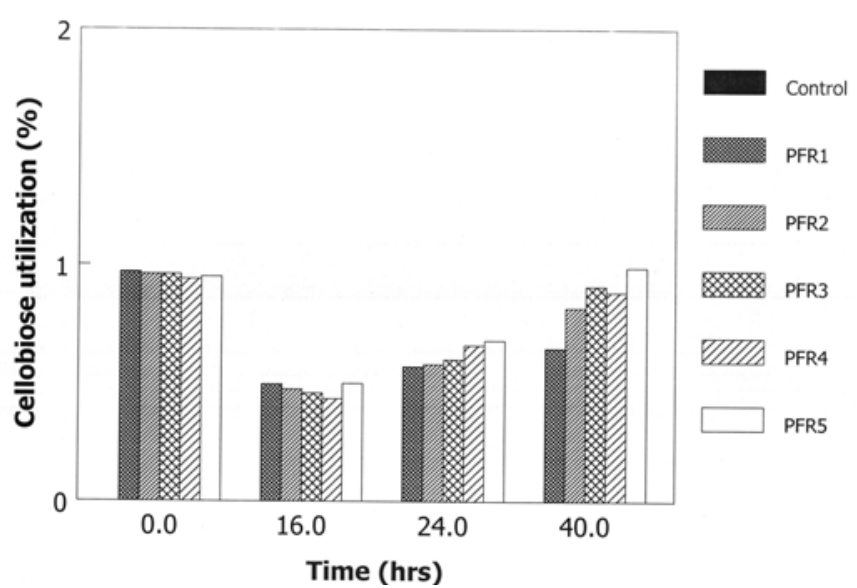

Figure 1. Utilization of cellulobiose by bombarded yeast cells at variable time intervals grown in $1 \%$ cellulose.

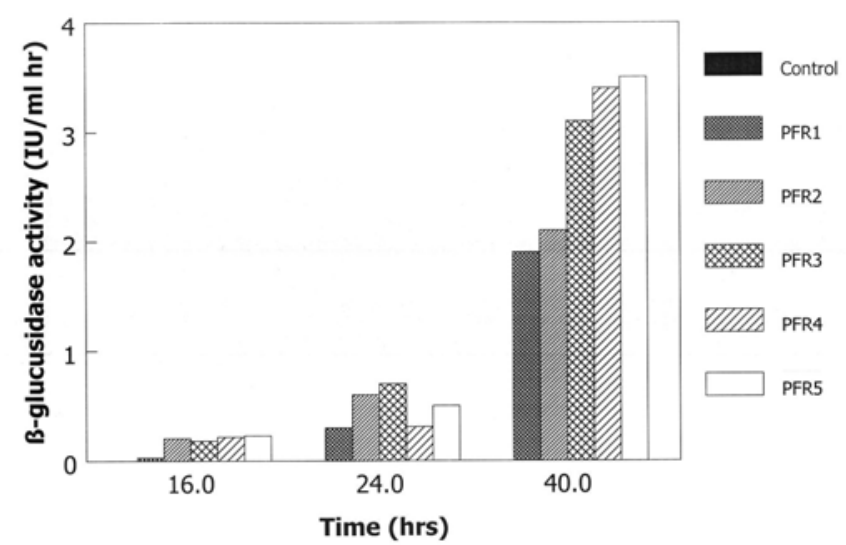

Figure 2. Production of beta-glucosidase by bombarded yeast habouring chromosomal DNA from $\mathrm{C}$. biazotea restricted with Sacl grown on $1 \%$ cellobiose after $40 \mathrm{~h}$. that of C. biazotea. In this study, the enzyme was mainly produced cell bound and the electrophoretic mobility of $\beta$-glucosidase from the donor as well as from the transformant was identical (not shown). There is possibility that the genes of other enzymes, possibly including cellobiose phosphorylase, may also have been transformed along with $\beta$-glucosidase.

This study will be helpful in applying this technique to other yeast or other fungi for which an effective transformation system is not available.

\section{ACKNOWLEDGEMENTS}

This research has been financed in part by a grant made by the Pakistan Science Foundation Project \# (219) and ( $\left.\mathrm{Cir}^{\circ}\right)$ strain FAS-21 of $S$. cerevisae were gift from ICGEB, Trieste Italy.

\section{REFERENCES}

Armaleo D, Ye GN, Klein TM, Shark KB, Sanford JC, Johnston SA (1990). Curr. Genet. 17: 97-103.

Ausubel FM, Brent R, Kingston RE, Moore DD, Seidman JG, Smith JA, Struhl K (1990). Current protocols in Molecular Biology. Green Publishing Associates and Wiley - John Wiley and Sons, New York.

Botstein D, Fink GR (1988). Yeast: an experimental organism for modern biology. Science, 240: 1439-1443.

Chen L, Zhang S, Beachy RN, Fauquet CM (1998). A protocol for consistent, large scale production of fertile transgenic rice plants. Plant Cell Rep. 18: 25-31.

Curry C, Gilkes N, Neill GO, Miller RC, Skipper N (1988). Expression and screening of $C$. fimi exoglucanase gene in $S$. cerevisiae Appl. Environ. Microbiol. 54: 476-84.

Dai S, Zheng P, Marmey P, Zhang S, Tian W, Chen S, Beachy RN, Fauquet C (2001). Comparative analysis of transgenic rice plants obtained by Agrobacterium-mediated and particle bombardment. Mol. Breed. 7: 25-33.

Del Rosario EJ, Lee KH, Rogers, PL. (1979). Kinetics of alcohol fermentation at high yeast levels. Biotechnol. Bioeng. 21: 1477-82.

Finer JJ, McMullen MD (1990). Transformation of cotton (Gossypium hirsutum L.) via particle bombardment. Plant Cell Rep. 8: 586-589.

Gilkes NR, Kilbern DG, Miller RC, Warren RAJ (1991). Precise excision of the Cellulose binding domain from two C. fimi . Cellulose by a homologous Protease and the effect of catalysis. Bioresource Technology 36: 21-35.

Johnston SA, Anziano PQ, Shark K, Sanford JC, Butow RA (1988). Mitochondrial transformation in yeast by bombardment with microprojectiles. Science, 240: 1538-1541.

Jordan MC (2000). Green fluorescent protein as a visual marker for wheat transformation. Plant Cell Rep. 19: 1069-1075.

Klein TM, Fromm M, Weissinger A, Tomes D, Schaaf S, Sletten M, Sanford JC (1987). High velocity microprojectiles for delivering nucleic acids into living cells. Nature, 327: 70-73.

Klein TM, Fromm M, Weissinger, A, Tomes D, Schaaf S, Sletten M, Sanford JC (1988a). Transfer of foreign genes into intact maize cells with high velocity microprojectiles. Proc. Natl. Acad. Sci. USA, 85: 43054309.

Klein TM, Gradziel T, Fromm M, Stanford JC (1988b). Factors influencing gene delivery into Zea mays cells by high velocity microprojectiles. Bio/Technol. 6: 559-563.

Knowles J, Lehtovaara P, Teeri T (1987). Cellulose families and their genes. Trends Biotechnol. 5: 255-261.

Marsden WL, Gray PP (1986). Enzymatic hydrolysis of cellulose in lignocellulosic materials. CRC Critical Reviews in Biotechnology, 3: 235-276. 
McCabe DE, Swain WF, Martinell, BJ, Christou P (1988). Stable transformation of soybean (Glycine max) by particle acceleration. Bio/Technol. 6: 923-926.

Nakamura K, Misawa N, Kitamura K (1986) Cellulase genes of Cellulomonas CB4. Cloning and expression of a CM-cellulose hydrolyzing enzyme (endoglucanase) gene in E. coli. J. Biotechnol. 3: 239-246.

Nakamura K, Kitamura K (1982). Isolation and identification of crystalline cellulose hydrolysing bacterium and its enzymic properties. J. Ferment. Technol. 60: 343-348.

Penttila M, Lehtovaara P, Knowles J (1989). In: Yeast Genetic Engineering. Eds. Barr et al Pubs. Butterworths, Singapore. pp. 247-268.

Rajoka, M.I. and Malik, K.A. (1986). Comparison of different strains of Cellulomonas for production of cellulolytic and xylanolytic activities from biomass produced on saline lands. Biotechnol. Letts. 8 (10): 753-756.
Rasco-Gaunt, S., Riley, A. and Lazzeri, P. (1999). Analysis of particle bombardment parameters to optimize DNA delivery into wheat tissues. Plant Cell Rep. 19: 118-127.

Sanford JC, Klein TM, Wolf ED, Allen N (1987). Delivery of substances into cells and tissues using a particle bombardment process. J. Particulate Sci. Technol. 5:27-37.

Wang YC, Klein TM, Fromm M, Cao J, Sanford JC, Wu R (1988). Transient expression of foreign genes in rice, wheat and soybean cells following particle bombardment. Plant Mol. Biol. 11: 433-440.

Weeks JT, Anderson OD, Blechl AE (1993). Rapid production of multiple independent lines of fertile transgenic wheat (Triticum aestivum)Plant Physiol., 102: 1077-1084.

Whittle DL, Kilburn DG, Warren RAJ, Miller RC (1982). Molecular cloning of a C.fimi cellulase gene in E.coli. Gene 17: 139-45. 